Prepared in cooperation with the Great Lakes Restoration Initiative

\title{
Seismic Data Collection from Water Gun and Industrial Background Sources in the Chicago Sanitary and Ship Canal Area, Illinois, 2011
}

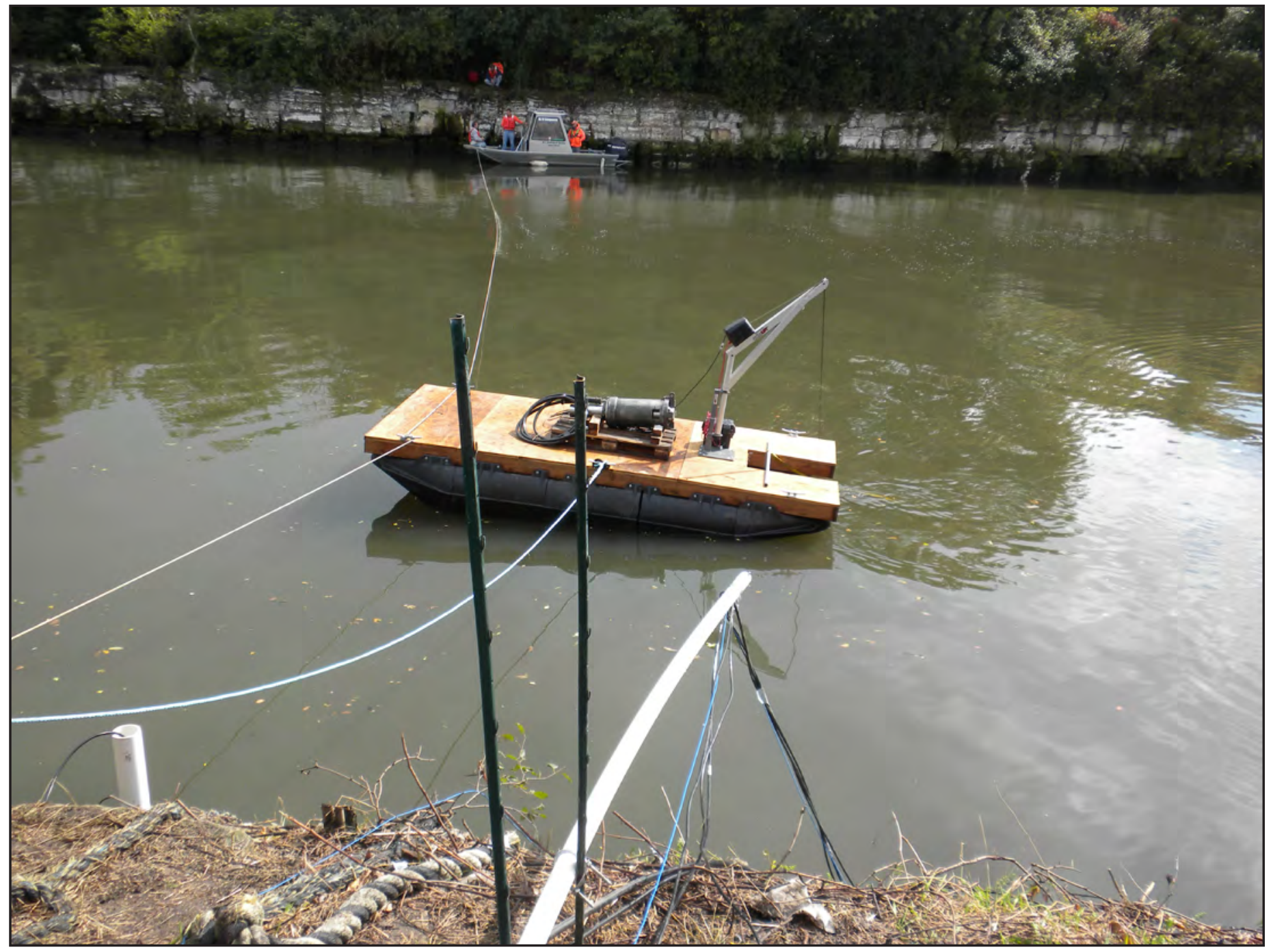

Data Series 938 
Front cover: Water gun setup in Chicago Sanitary and Ship Canal near Lemont, Illinois, September 2011. For more details, see figure 6. 


\section{Seismic Data Collection from Water Gun and Industrial Background Sources in the Chicago Sanitary and Ship Canal Area, Illinois, 2011}

By William S. Morrow, Philip J. Carpenter, and Ryan F. Adams

Prepared in cooperation with the Great Lakes Restoration Initiative

Data Series 938 


\title{
U.S. Department of the Interior SALLY JEWELL, Secretary
}

\section{U.S. Geological Survey \\ Suzette M. Kimball, Acting Director}

\author{
U.S. Geological Survey, Reston, Virginia: 2015
}

For more information on the USGS - the Federal source for science about the Earth, its natural and living resources, natural hazards, and the environment—visit http://www.usgs.gov or call 1-888-ASK-USGS.

For an overview of USGS information products, including maps, imagery, and publications, visit http://www.usgs.gov/pubprod/.

Any use of trade, firm, or product names is for descriptive purposes only and does not imply endorsement by the U.S. Government.

Although this information product, for the most part, is in the public domain, it also may contain copyrighted materials as noted in the text. Permission to reproduce copyrighted items must be secured from the copyright owner.

Suggested citation:

Morrow, W.S., Carpenter, P.J., and Adams, R.F., 2015, Seismic data collection from water guns and industrial background sources in the Chicago Sanitary and Ship Canal Area, Illinois, 2011: U.S. Geological Survey Data Series 938, 23 p., http://dx.doi.org/10.3133/ds938.

ISSN 2327-638X (online) 


\section{Contents}

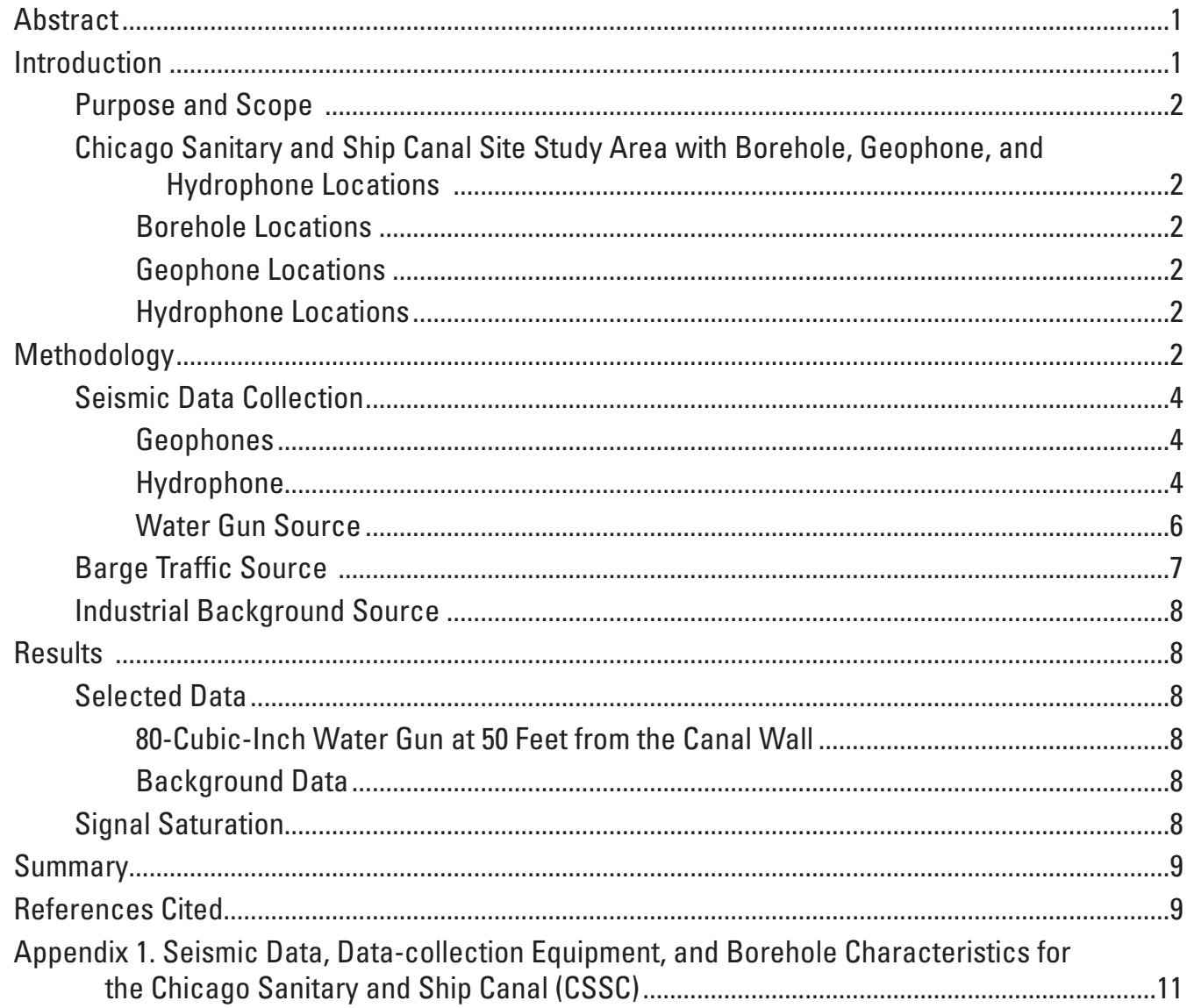

\section{Figures}

1. Location of the Lemont test area, data collection areas, and the electric fish barrier on the Chicago Sanitary and Ship Canal between Romeoville and Lemont, Illinois .........3

2. Schematic of the Lemont test area..................................................................................

3. Closeup view and equipment at $A$, the Lemont test area; $B$, Coal plant data collection area; and $C$, Electric fish barrier data collection area, on the Chicago Sanitary and Ship Canal between Romeoville and Lemont, Illinois ..........................................................5

4. Water gun with piston size of 343 cubic inches ...............................................................6

5. Water gun with piston size of 80 cubic inches ...............................................................6

6. Water gun setup in canal 30 feet from canal wall (hydrophone cable extending from white pipe, borehole with geophone cable)...

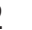
2 2

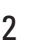
4

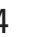

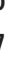

$$
8
$$
, .

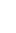
9 1 (1) 


\section{Conversion Factors}

Inch/Pound to International System of Units

\begin{tabular}{lcl}
\hline \multicolumn{1}{c}{ Multiply } & By & \multicolumn{1}{c}{ To obtain } \\
\hline inch (in.) & Length & \\
inch (in.) & 2.54 & centimeter $(\mathrm{cm})$ \\
foot (ft) & 25.4 & millimeter $(\mathrm{mm})$ \\
mile (mi) & 0.3048 & meter $(\mathrm{m})$ \\
& 1.609 & kilometer $(\mathrm{km})$ \\
\hline cubic inch $\left(\mathrm{in}^{3}\right)$ & Volume & \\
cubic inch $\left(\mathrm{in}^{3}\right)$ & 16.39 & cubic centimeter $\left(\mathrm{cm}^{3}\right)$ \\
cubic inch $\left(\mathrm{in}^{3}\right)$ & 0.01639 & cubic decimeter $\left(\mathrm{dm}^{3}\right)$ \\
\hline & 0.01639 & liter $(\mathrm{L})$ \\
\hline pound per square inch $\left({\left.\mathrm{lb} / \mathrm{in}^{2}\right)}^{\text {bar }}\right.$ & Pressure & \\
\hline
\end{tabular}




\title{
Seismic Data Collection from Water Gun and Industrial Background Sources in the Chicago Sanitary and Ship Canal Area, Illinois, 2011
}

\author{
By William S. Morrow, ${ }^{1}$ Philip J. Carpenter, ${ }^{2}$ and Ryan F. Adams ${ }^{1}$
}

\section{Abstract}

The water gun is a tool adapted from deep marine geophysical surveys that is being evaluated for use as an acoustic fish deterrent to control the movement of invasive marine species. The water gun creates a seismic signal by using a compressed air discharge to move a piston rapidly within the water, resulting in an implosion. This energy pulse may be able to modify fish behavior or destroy marine life, such as the Asian carp, at some distance. The effects of this energy pulse on structures in the Chicago Sanitary and Ship Canal (CSSC), such as canal walls, shore lines, and lock structures, are not known. The potential effects of the use of a water gun on structures was identified as a concern in the CSSC and was assessed relative to existing background sources during this study. During September 2011, two water guns with piston sizes of 80 and 343 cubic inches, respectively, were tested in the CSSC at varying pressures and distances from a canal wall consisting of dolomite and dolomite setblock. Seismic data were collected during these water gun firings using geophones on land, in boreholes, and at the canal wall interface. Data were collected at varying depths in the canal water using hydrophones. Seismic data were also collected during the occurrences of barge traffic, railroad traffic located near the electric fish barrier in Lemont, and coal-loading operations at a coal power plant near the electric fish barrier. In general, energy produced by barge and railroad sources was less than energy created by the water gun. Energy levels produced by coal-loading operations at least 200 feet from geophones were approximately four times lower than energy levels measured during water gun operations.

\footnotetext{
${ }^{1}$ U.S. Geological Survey.
}

${ }^{2}$ Northern Illinois University.

\section{Introduction}

The water gun is a device that produces a seismic energy source by moving a 1 to 343 -cubic-inch $\left(\mathrm{in}^{3}\right)$ piston rapidly within the water, creating an implosion, shock wave, and a resulting seismic energy pulse. The water gun may be able to deter or kill fish (Gross and others, 2013; Keevin and Hempen, 1997). The Asian carp is an aquatic invasive species that is extending their habitat upstream in the Illinois River. The Illinois River is connected with Lake Michigan through the Chicago Area Waterway System (CAWS) and the Chicago Sanitary Ship Canal (CSSC). This waterway connection makes possible the introduction of Asian carp into Lake Michigan. Because of this possible ability to destroy or repel marine life at some distance, water guns have been proposed to be used as a method to control or remove Asian carp in the vicinity of the electric fish barriers and other possible locations in CAWS and downstream of the CAWS. The magnitude and potential impact of vibrations (energy generated) resulting from the use of water gun(s) on structures, such as the lock controlling works, the electric barrier, and canal walls, is unknown. Seismic data were collected from an area of the CSSC during testing of the 80 - and $343-$ in $^{3}$ water guns to measure vibrations to initially assess potential effects produced relative to other background sources, such as barges, railroad traffic, and coalloading operations. Recordings of seismic data produced from other sources present in the vicinity of the CSSC include: (1) barge traffic along the CSSC, (2) railroad traffic located near the electric fish barrier in Lemont, and (3) coal-loading operations at a coal power plant also near the electric fish barrier. The data were received with geophones and hydrophones on the surface, in boreholes, along the canal wall, and within the canal water. These seismic data records are presented here to give a comparative energy output of the water gun relative to existing background energy, so possible effects on the structures and canal walls from the water gun use may be evaluated relative to current vibration sources. This project was funded through the Great Lakes Restoration Initiative as administered by the U.S. Environmental Protection Agency. 


\section{Purpose and Scope}

The purpose of this geophysical investigation is to improve the understanding of the relative energy output of the water gun that could potentially be used to control invasive species in the CAWS by presenting geophysical data that can be used to characterize ground vibrations resulting from the use of a water gun as a fish deterrent in the CAWS. Ground vibration intensity, in terms of particle velocities and frequencies produced by the water gun, can be compared to the ground vibrations produced by barge traffic and industry near the fish barrier (coal power plant and rail traffic). Seismic energy from these sources was measured by geophones on the land surface, in boreholes, and at the canal wall; hydrophones were used in water. These data show the relative difference in energy among the sources, but determining whether structures would be damaged, such as canal walls, is beyond the scope of this report. Seismic data discussed in this report are stored online in the SEG-2 format, a standard geophysical data file format. Seismic data can be accessed through standard geophysical software capable of reading SEG-2 files. Software capable of reading SEG-2 format is also freely available and documented in U.S. Geological Survey (USGS) Open-File Report 03-141 (Ellefsen, 2003), available at http://pubs.usgs. gov/of/2003/ofr-03-141. Other open-source software, such as Geopsy (available at http://www.geopsy.org/), are available to read SEG-2 formatted data. The digital data are available at http://dx.doi.org/10.3133/ds938/.

\section{Chicago Sanitary and Ship Canal Site Study Area with Borehole, Geophone, and Hydrophone Locations}

The location for testing within the Chicago Sanitary and Ship Canal (CSSC) was chosen based on the site being topographically and geologically similar to the electric fish barrier site. Dolomite or dolomite setblock comprises the channel walls. The width of the canal at the testing point was approximately $167 \mathrm{ft}$, with an approximate canal depth of $25 \mathrm{ft}$ during testing. The location is approximately 5 miles upstream from the electric fish barrier near River Mile 301.5 (fig. 1).

\section{Borehole Locations}

Three boreholes were installed at the site using mud rotary drilling. The locations of the boreholes are in an approximate straight line at 5,35, and $100 \mathrm{ft}$ away from the north canal wall. All three boreholes had water levels approximately the same elevation as the CSSC water level.

The borehole $5 \mathrm{ft}$ from the canal wall (3-in. diameter) was drilled to $29.5 \mathrm{ft}$ below ground surface (bgs) with $10 \mathrm{ft}$ of casing (top portion). Stickup was $0.1 \mathrm{ft}$ above the ground surface.

The borehole $35 \mathrm{ft}$ from the canal wall (4-in. diameter) was drilled to $39.4 \mathrm{ft}$ bgs with $20 \mathrm{ft}$ of casing. Stickup was $1.2 \mathrm{ft}$ above ground surface.

The borehole $100 \mathrm{ft}$ from the canal wall (4-in. diameter), was drilled to $35 \mathrm{ft}$ bgs with $15 \mathrm{ft}$ of casing. Stickup was $0.24 \mathrm{ft}$ above ground surface. See figure 2 .

\section{Geophone Locations}

Three-component (3C) geophones consisting of two horizontal-motion sensors and one vertical-motion sensor were deployed at the land surface adjacent to boreholes. These landsurface geophones were leveled and coupled to the ground using three spikes affixed to the bottom of the geophone. The longitudinal axis of the geophones (channel 2) was oriented with the pointed end of the geophone, which was perpendicular to the canal.

Three-component downhole geophones (two horizontal components and one vertical component) were secured in position using springs expanded against the borehole wall in the three boreholes located at 5, 35, and $100 \mathrm{ft}$ from the canal. Two geophones were installed at each borehole, with one geophone $5 \mathrm{ft}$ bgs and the other deeper geophone ranging from 20-25-ft bgs to approximate the elevation of the water gun.

One 3C downhole geophone was installed in a 3-in-diameter polyvinyl chloride (PVC) pipe that was secured against the side of the canal wall. The $3 \mathrm{C}$ geophone was installed approximately $2 \mathrm{ft}$ below water surface.

\section{Hydrophone Locations}

Three hydrophones were installed approximately $3 \mathrm{ft}$ away from the canal wall. These hydrophones were installed on one cable and were spaced at 8 -ft intervals. The approximate depths of these hydrophones were at 3,11 , and $19 \mathrm{ft}$ below water surface (fig. 2).

\section{Methodology}

Water gun and background-barge data acquisition occurred from September 26-29, 2011. Industrial-background seismic-data acquisition from the coal power plant and the railroad adjacent to the electric fish barrier occurred on October 20 and November 1, 2011 (fig. 3). Personnel involved with data collection were from the USGS Illinois Water Science Center (Urbana and DeKalb, Illinois), Northern Illinois University (NIU), the Northern Rocky Mountain Science Center (Missoula, Montana), and Bolt Technology (Norwalk, Connecticut). 


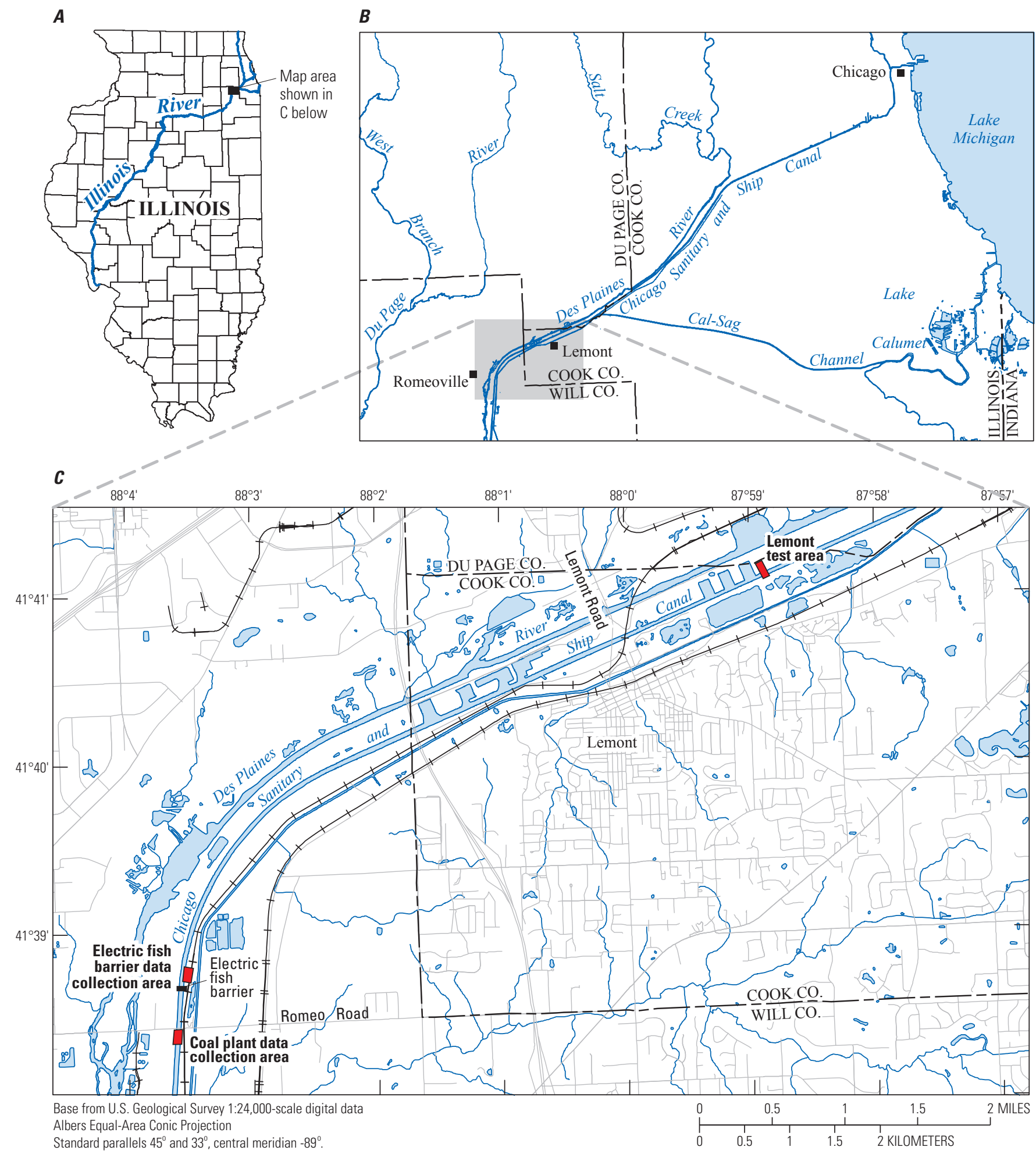

Figure 1. Location of the Lemont test area, data collection areas, and the electric fish barrier on the Chicago Sanitary and Ship Canal between Romeoville and Lemont, Illinois. 


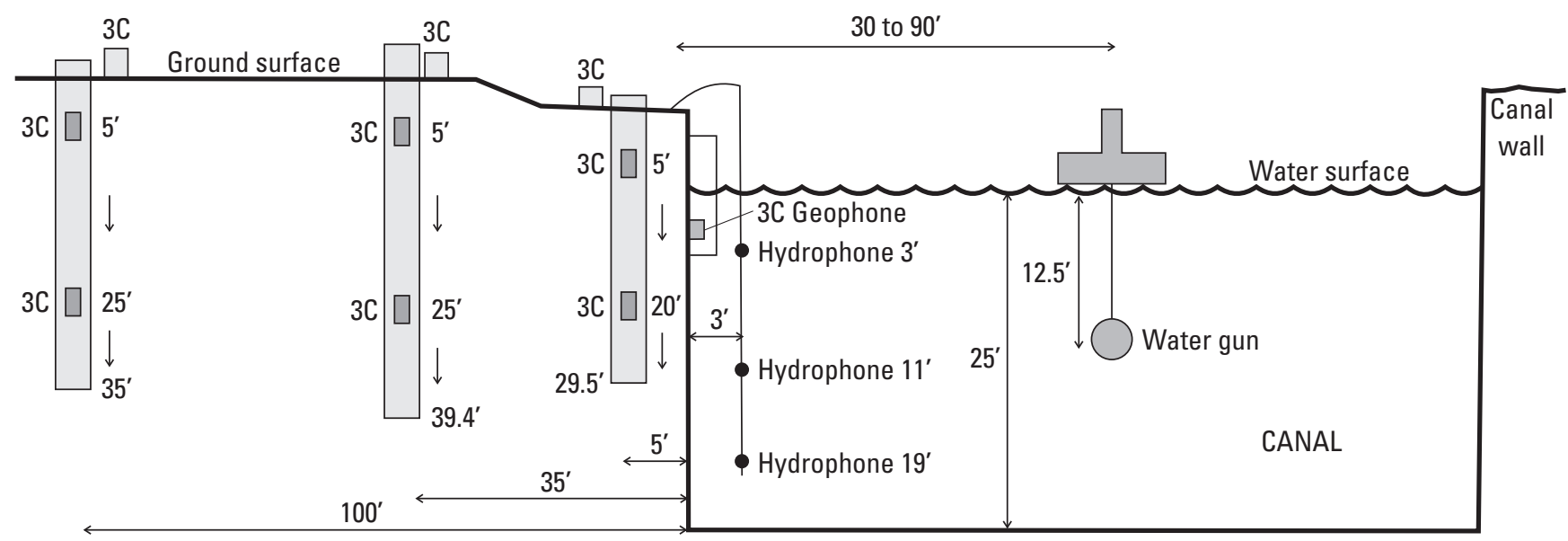

Figure 2. Schematic of the Lemont test area.

\section{Seismic Data Collection}

Data were collected using a Geometrics Geode 24-channel seismograph with single Geode operating software (SGOS). A multiple Geode operating software (MGOS) was used on the final day of testing. Data collection was initiated manually. All geophones and hydrophones were channeled through routing switchboxes to the Geode seismograph, which digitized and recorded all signals. The Geode data were collected using the upper range of the low gain setting on the Geode seismograph, resulting in 24 decibels of gain before signal amplification, a signal magnification factor of approximately 16 . Sampling time length for water gun data collection was either 8 seconds (s) at a 0.125 -millisecond (ms), or $8 \mathrm{~s}$ at a 0.5 -ms sampling interval. Sampling time for background collection was $240 \mathrm{~s}$ at a 16-ms sampling interval.

\section{Geophones}

All geophone data are output in millivolts $(\mathrm{mV})$. Threecomponent geophones manufactured by RT Clark, having a frequency of $10 \mathrm{Hertz}(\mathrm{Hz})$, coil resistance of $395 \mathrm{ohms,}$ and a sensitivity of 27.5 volts $(\mathrm{V}) /(\mathrm{m} / \mathrm{s})$, were used for all surface locations. Mark Products 3C, horizontal, and vertical geophones, owned by Northern Illinois University, were also deployed. These included the 3C L-15B geophones (4.5-Hz natural frequency), the vertical component L-10B (4.5-Hz natural frequency), L-40 A3 geophones (40-Hz natural frequency), and the horizontal L-28LBH geophones $(4.5-\mathrm{Hz}$ natural frequency).
Downhole 3C land geophones manufactured by RT Clark, having a frequency of $10 \mathrm{~Hz}$, coil resistance of 395 ohms, and a sensitivity of $27.5 \mathrm{~V} / \mathrm{m} / \mathrm{s}$, were used in the three boreholes and the 3 -in. PVC pipe affixed to the side of the canal wall. The geophones were held in place at the desired elevation by attached steel springs that were manually released causing the springs to expand and seat firmly against the borehole.

\section{Hydrophones}

The primary hydrophones were three hydrophones constructed as one in-line cable with a spacing of $8 \mathrm{ft}$ between hydrophones. The hydrophones were High Tech HTI-96-Min hydrophones with no preamplifier. The hydrophones have a sensitivity of $8.9 \mathrm{~V} / \mathrm{bar}$. All hydrophone data are in $\mathrm{mV}$.

Prior to using the hydrophone string for recording, two "sacrificial" OYO Geospace MP-24-L3 hydrophones, with a sensitivity of $7.5 \mathrm{~V} / \mathrm{bar}$, were used to determine if hydrophone usage was feasible at the shot pressure and distance to the water gun. Water gun shots were fired at $30-\mathrm{ft}$ distances to determine potential damage to the hydrophones. No rupturing or damage was determined to have occurred and the High Tec hydrophone string was determined to be safe to use at a distance of $30 \mathrm{ft}$. 


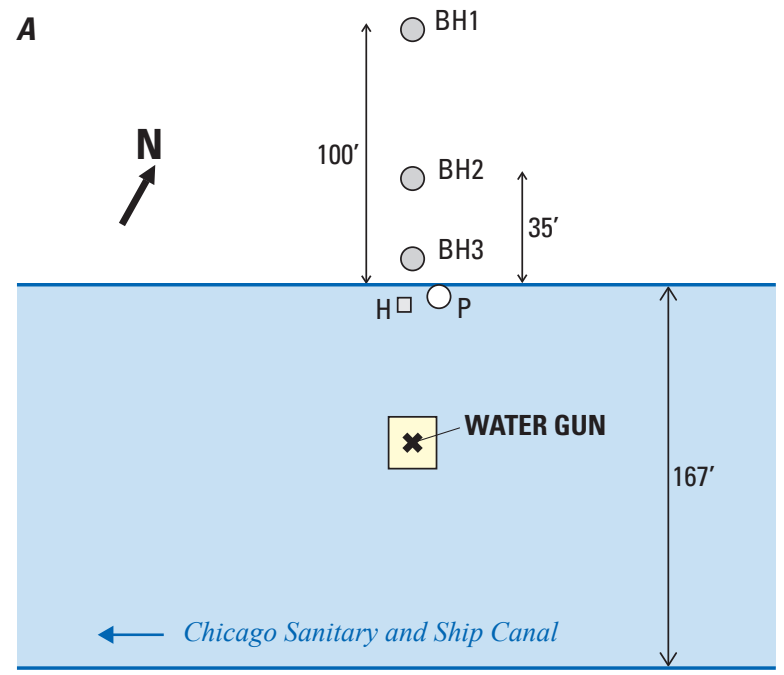

BH1-Borehole 1, 100 feet from canal wall BH2-Borehole 2, 35 feet from canal wall BH3-Borehole 3, 5 feet from canal wall $\mathrm{H}-$ Hydrophones location

P-PVC pipe affixed to canal wall

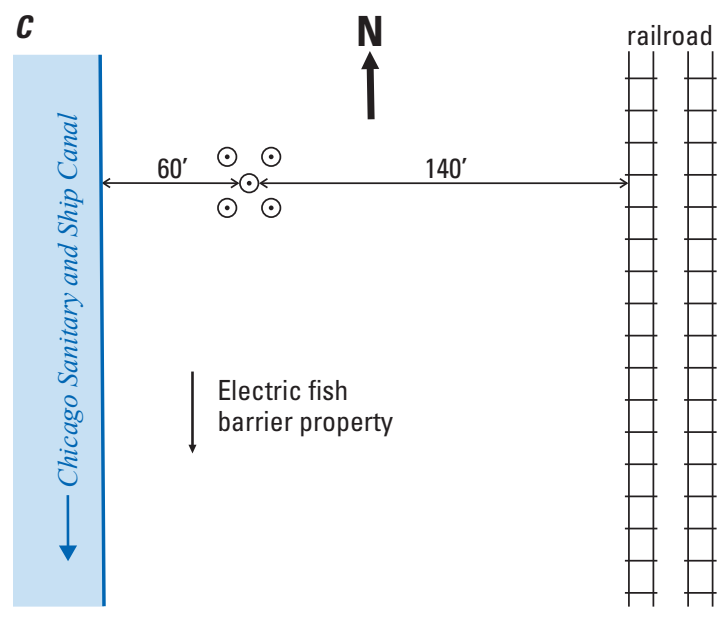

B

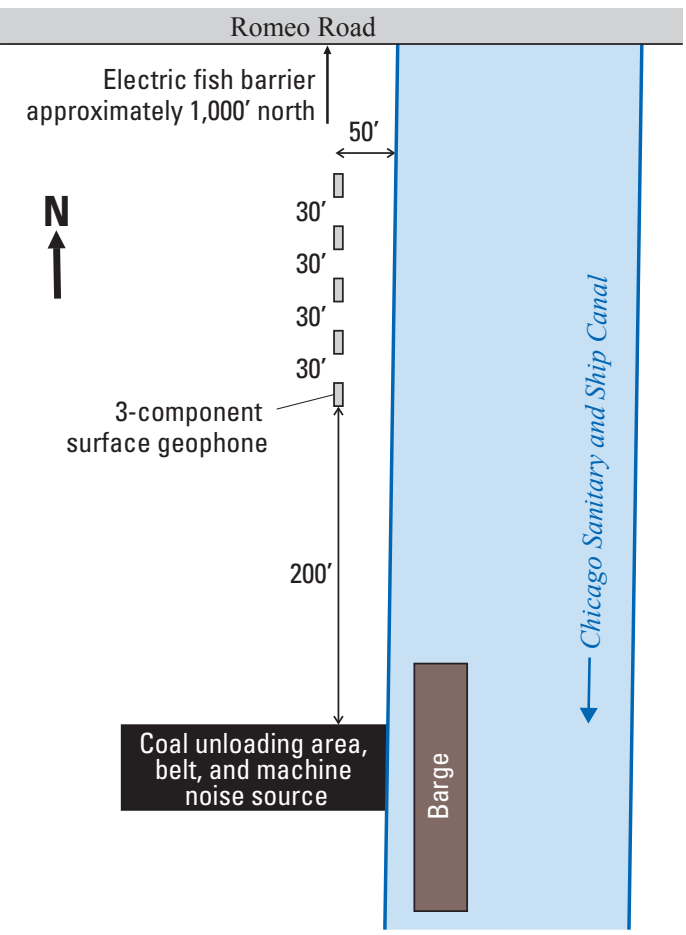

Figure 3. Closeup view and equipment at $A$, the Lemont test area; $B$, Coal plant data collection area; and $C$, Electric fish barrier data collection area, on the Chicago Sanitary and Ship Canal between Romeoville and Lemont, Illinois. 


\section{Water Gun Source}

Two water guns were used in the test - a Bolt Model P400 343-in ${ }^{3}$ gun (fig. 4) and a Bolt model S80 80-in ${ }^{3}$ gun (fig. 5). An additional Bolt model 10B 1-in ${ }^{3}$ gun was available but not fired. The water gun creates an energy pulse by rapidly moving a piston, ejecting water from the chamber area, and creating a cavity. This produces an implosion that sends a high-frequency energy pulse through the water. This energy pulse is relatively short, bubble free, and has more high-frequency energy and less low-frequency energy than the air gun (Hutchinson, 1984).

Two water guns were individually fired during testing the $343-\mathrm{in}^{3}$ water gun and the $80-\mathrm{in}^{3}$ water gun. Water guns were secured on a hoist to a floating raft, which was secured to a tagline affixed to each side of the canal wall (fig. 6). The water guns were lowered to $12.5 \mathrm{ft}$ below water surface, approximately half the canal depth.
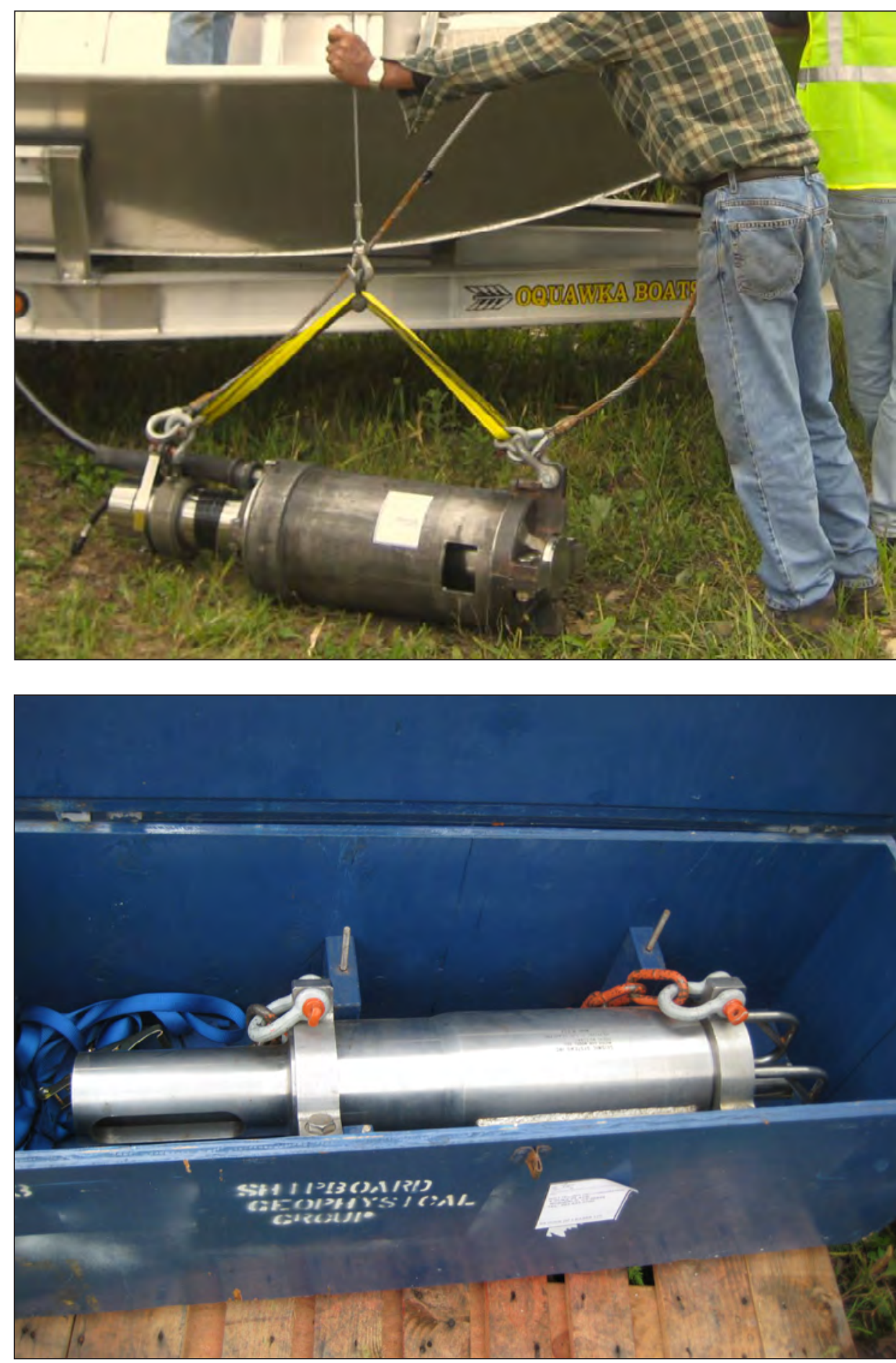

Figure 4. Water gun with piston size of 343 cubic inches.
Figure 5. Water gun with piston size of 80 cubic inches. 


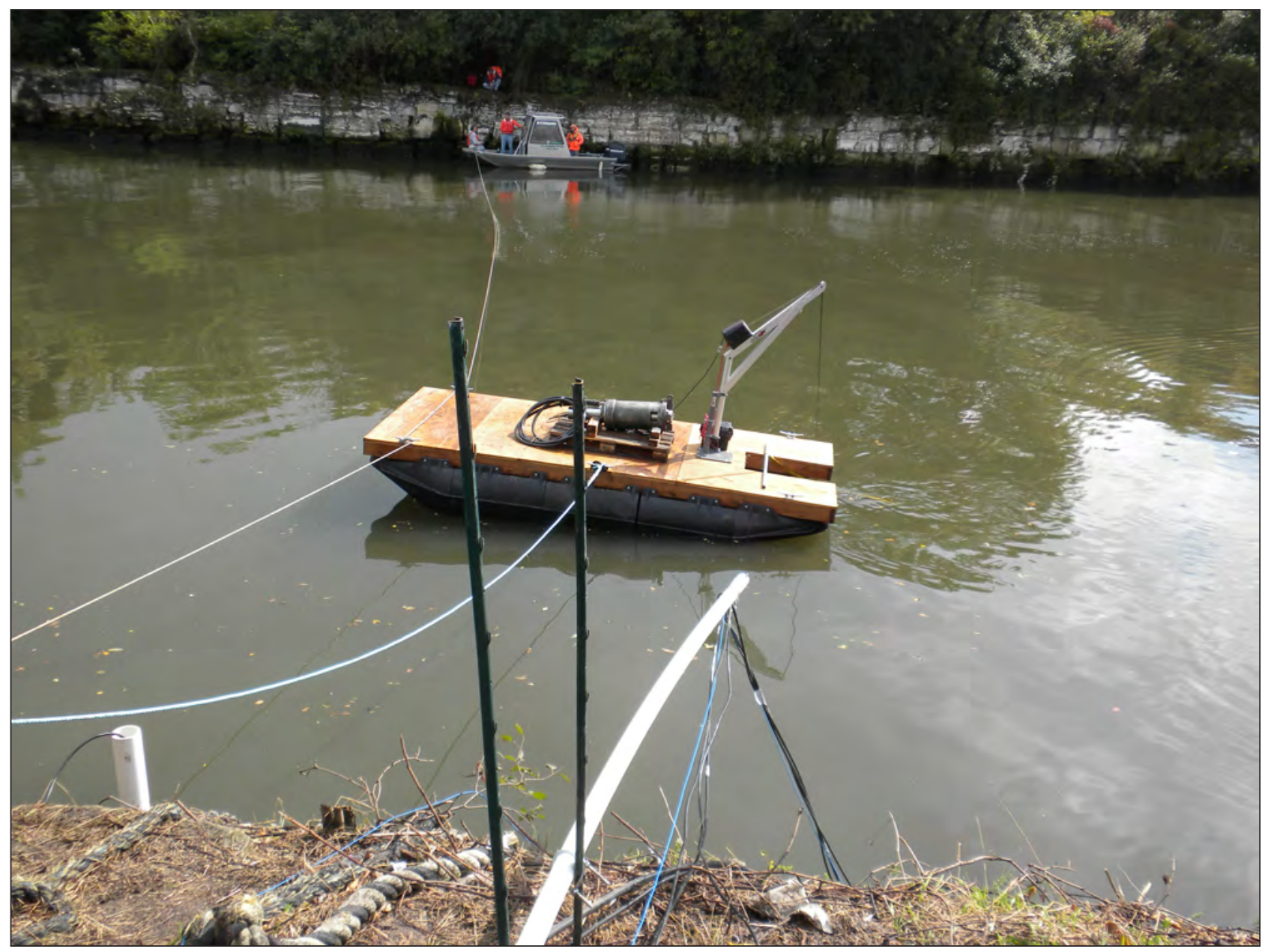

Figure 6. Water gun setup in canal 30 feet from canal wall (hydrophone cable extending from white pipe, borehole with geophone cable).

The 343 -in ${ }^{3}$ water gun was initially located $90 \mathrm{ft}$ from the canal wall, greater than half the $167-\mathrm{ft}$ width of the canal, and fired at 2,000 pounds per square inch $\left(\mathrm{lb} / \mathrm{in}^{2}\right)$. Ten separate successful water gun firing datasets were collected at 90, 80, $70,60,50,40$, and $30 \mathrm{ft}$ from the canal wall, thus generating 70 datasets in total. Data collection was stopped at $30 \mathrm{ft}$ based on previous reports of hydrophones potentially being damaged at distances less than $30 \mathrm{ft}$ (J. Gross, U.S. Geological Survey, oral commun., 2011).

The $80-\mathrm{in}^{3}$ water gun was then attached and lowered to approximately $12.5 \mathrm{ft}$ below water surface. Ten successful water gun firing datasets were collected at 30,40 , and $50 \mathrm{ft}$ away from the canal wall.

At the conclusion of successful data collection with the $343-\mathrm{in}^{3}$ and $80-\mathrm{in}^{3}$ guns collecting concurrent hydrophone and 3C (downhole and land) geophone data, surface P and S (4.5 $\mathrm{Hz}$ ) surface geophones were installed approximately the same distance from the canal wall as the 5 -ft borehole. Data were then collected with the $80-\mathrm{in}^{3}$ gun at $2,000 \mathrm{lb} / \mathrm{in}^{2}$ with the water gun located $30 \mathrm{ft}$ from the canal wall. Data for the water guns were collected at a $0.125-\mathrm{ms}$ sampling interval for $8 \mathrm{~s}$.

\section{Barge Traffic Source}

Potential background noise was recorded while 12 barges and several recreational boats passed through the canal during the period of the water gun testing. Water gun testing was suspended during boat traffic. These datasets were determined to be a better comparison than the planned collection of background barge traffic approximately 0.7 mile upstream at the existing USGS gaging station because of the identical layout of geophones and hydrophones and geologic conditions. Data for barge traffic were collected at either a 1-ms sampling interval for $60 \mathrm{~s}$ or at $16-\mathrm{ms}$ intervals for $260 \mathrm{~s}$ (4.33 minutes). Some background noise records were also made without barge or boat traffic. 


\section{Industrial Background Source}

Industrial-background seismic data were collected at the coal power plant approximately 1,000 ft downstream from the electric fish barrier. Seismic data were also collected while freight trains were passing near the electric fish barrier. A crushed rock and gravel operation immediately south of the coal power plant did not have a suitable location to locate geophones in relation to the canal and the primary seismic source (conveyor belt and crane loading of material onto barges), but the operational energy from the rock and gravel operation was considered approximately equal to the coal power plant source (based on conveyor belt and crane loading of similar material onto barges). A refinery located within the area of the electric fish barrier was determined to be located far enough away not to be a significant seismic source, based on personal observation.

Five $3 \mathrm{C}$ surface geophones were installed in a northsouth line away from a potential seismic source-a conveyor belt approximately $50 \mathrm{ft}$ from the canal wall and leading to a crane that loaded coal onto barges. The largest noise source was the coal hitting the barge container during loading. The closest geophone in the line was approximately $200 \mathrm{ft}$ away from the location where barges are loaded (fig. 3). The five geophones were spaced every $30 \mathrm{ft}$ and were anchored in loose granular coal. Continuous data were collected during the loading of coal to a barge. Data for energy transmitted by coal being loaded and (or) unloaded were collected at 16-ms (0.016-s) intervals for $260 \mathrm{~s}$.

Seismic data were collected during the passing of freight trains (potential seismic sources) on site at the north end of the electric fish barrier. The 3C surface geophones were located in a 25-ft-square array with one geophone centrally located. Pointed tips of geophones (channel 2) were oriented north. The center of the square array was approximately $60 \mathrm{ft}$ east from the canal wall and approximately $140 \mathrm{ft}$ west of the edge of the railroad tracks (fig. 3). Data were recorded while seven freight trains passed near the electric fish barrier site. Data for freight train traffic were collected at $16-\mathrm{ms}$ intervals for $260 \mathrm{~s}$.

\section{Results}

Signals from seismic energy sources, including water gun firings, barge traffic, freight train traffic, and a coal-loading facility, were recorded by seismographs; datasets are cataloged in appendix 1. Raw digital data files are available at http:// dx.doi.org/10.3133/ds938/. All values are in mV. Geophone data may be converted to ground motions (ground velocity) using the conversion factor of 0.698 Volt per inch per second (V/in/s). Hydrophone conversion from $\mathrm{mVs}$ to $\mathrm{lb} / \mathrm{in}^{2}$ are affected by an unknown error factor resulting from cable length and cable composition; therefore, hydrophone $\mathrm{mV}$ data should not be used in direct computation of $\mathrm{lb} / \mathrm{in}^{2}$.

\section{Selected Data}

All dataset files are available at http://dx.doi.org/10.3133/ ds938/ and viewable with software that is capable of reading SEG-2 format available in U.S. Geological Survey Open-File Report 01-141 (Ellefsen, 2003). Other open-source software, such as Geopsy (available at http://www.geopsy.org/), are available to read SEG-2 formatted data. Selected data are documented below.

\section{0-Cubic-Inch Water Gun at 50 Feet from the Canal Wall}

Ten datasets were recorded when the $80-\mathrm{in}^{3}$ gun was fired at 2,000 lb/in $50 \mathrm{ft}$ from the wall. Maximum signal from the surface $3 \mathrm{C}$ geophones at 5, 35, and $100 \mathrm{ft}$ were 89,45 , and 12 $\mathrm{mV}$, respectively. The maximum for the PVC pipe data was 86 $\mathrm{mV}$. The hydrophone data maximum value was $89 \mathrm{mV}$.

\section{Background Data}

Barge datasets maximums for surface $3 \mathrm{C}$ geophones from 5, 35, and $100 \mathrm{ft}$ were 4, 3, and $1 \mathrm{mV}$, respectively. Maximum data value for the PVC pipe ranged from less than 1 to more than $100 \mathrm{mV}$. Maximum data for the hydrophone streamer ranged from less than 1 to more than $100 \mathrm{mV}$.

Railroad noise near the fish barrier collected from passing freight trains approximately $140 \mathrm{ft}$ distant from surface $3 \mathrm{C}$ geophones produced a maximum output of approximately 1 $\mathrm{mV}$ on October 20, 2011, and $2.5 \mathrm{mV}$ (erroneous spikes on one geophone from 8.dat were not used) for data collected on November 1, 2011. No background hydrophone data were collected.

Signals recorded adjacent to the coal power plant with surface $3 \mathrm{C}$ geophones had a maximum value of $31 \mathrm{mV}$. Data were not recorded with hydrophones at this location.

\section{Signal Saturation}

During the processing and review of this dataset, it was determined that the seismic and pressure signals at close distances saturated the amplifiers and placed artificial limitations on the range resulting in clipping of signals recorded by the seismograph. Clipping occurred in signals received from geophones placed in the borehole that was $5 \mathrm{ft}$ from the canal wall, the geophone located in the PVC tube mounted on the canal wall, and hydrophones. These data were not included. Data collected at $35 \mathrm{ft}$ and further are unaffected for all datasets. A $90-\mathrm{mV}$ signal response should be considered a minimum value for saturation and clipping to occur; data exceeding 90 $\mathrm{mV}$ should be examined for possible saturation and clipping. 


\section{Summary}

The water gun is a potential method of controlling Asian carp within the Chicago Area Waterway System (CAWS), notably in the Chicago Sanitary and Ship Canal (CSSC) within the vicinity of the electric fish barrier. There is concern that energy released from water gun use may negatively affect the canal walls, structures, and (or) the equipment necessary to maintain the fish barrier. The potential effect of the use of a water gun on the canal wall and structures in the CSSC was assessed and compared to other existing background energy sources. To determine the relative energy outputs of the water gun operation relative to other energy sources, such as barge traffic and industrial-background noise, relative energy outputs were determined from each source. Two water guns (80- and 343- in ${ }^{3}$ pistons) were fired at various locations within the canal. Data were collected from hydrophones in the canal. Data were also collected from geophones at the canal wall/water interface, on land, and in boreholes at the approximate elevation of the water gun, at 5, 35, and 100 $\mathrm{ft}$ from the canal wall. In general, energy produced by barge and railroad sources was less than energy created by the water gun. Coal-loading operations approximately $200 \mathrm{ft}$ (or further) from geophones produced maximum energy levels that were approximately four (or less) times less energy than water gun operations.

\section{References Cited}

Ellefsen, K.J., 2003, seg2_edit: A program for editing and manipulating SEG-2 files: U.S. Geological Survey Open-File Report 03-141, 11 p.

Gross, J.A., Irvine, K.M., Wilmoth, S., Wagner, T.L., Shields, P.A., and Fox, J.R., 2013, Effects of pulse pressure from seismic water gun technology on Northern pike: Transactions of the American Fisheries Society, v. 142, no. 5, p. 1335-1346.

Hutchinson, D.R., and Detrick, R.S., 1984, Water gun vs. air gun; A comparison: Marine Geophysical Research, v. 6, no. 3, p. 295-310.

Keevin, T.M., and Hempen, G.L., 1997, The environmental effects of underwater explosions with methods to mitigate impacts: St. Louis, Missouri, U.S. Army Corps of Engineers. 



\section{Appendix 1. Seismic Data, Data-collection Equipment, and Borehole Characteristics for the Chicago Sanitary and Ship Canal (CSSC)}

\section{Seismic Data}

Seismic data in this report are online in the SEG-2 format at http://dx.doi.org/10.3133/ds938/. Seismic data can be accessed through standard geophysical software that is capable of reading SEG-2 files. Software capable of reading SEG-2 format is available and documented in U.S. Geological Survey (USGS) Open-File Report 01-141 (Ellefsen, 2003) available at http://pubs.usgs.gov/of/2003/ofr-03-141/. Other open-source software, such as Geopsy (available at http://www.geopsy. org/), are available to read SEG-2 formatted data. The data files are arranged in the following folders:

- September 27 2011th-CSSC

- September28_2011-CSSC

- September 29_2011-CSSC

- Oct 20_2011-Coal Plant

- Nov 1_2011-Rail Road

\section{Equipment}

Data were collected using Geometrics Geode seismographs and collected on personal computers using Single Geode Operating System (SGOS) and Multiple Geode Operating System (MGOS) software.

Three types of three-component (3C) sensors were deployed: RTClark 10-Hz surface geophones, RTClark 10-Hz downhole geophones, and Mark Products L15B 4.5-Hz surface geophones. Each of the three components corresponds to channels as shown below:

\section{0-Hz surface geophones}

- Channel 1: transverse component

- Channel 2: longitudinal component

- Channel 3: vertical component

\section{0-Hz borehole geophones}

- Channel 1: transverse component

- Channel 2: transverse component
- Channel 3: vertical component

Orientation of transverse components within the boreholes was unknown, due to rotation of the geophones before they were attached to the borehole wall. The orientation of components of the tube geophone on the canal wall was established through tap tests, as described below.

\section{5-Hz surface geophones}

- Channel 1: vertical component

- Channel 2: longitudinal component (referred to as H-1)

- Channel 3: transverse component (referred to as H-2)

\section{Borehole Characteristics}

\section{Borehole 1: $5 \mathrm{ft}$ from the canal wall}

- Depth - 29.5 feet (ft) below ground surface

- Diameter - 3 inches (in.)

- Casing $-10 \mathrm{ft}$

- Stickup $-0.1 \mathrm{ft}$ above ground surface

\section{Borehole 2: $35 \mathrm{ft}$ from the canal wall}

- Depth - 39.4 ft below ground surface

- Diameter -4 in.

- Casing $-20 \mathrm{ft}$

- Stickup - $1.2 \mathrm{ft}$ above ground surface

\section{Borehole 3: $100 \mathrm{ft}$ from the canal wall}

- Depth - $35.0 \mathrm{ft}$ below ground surface

- Diameter -4 in.

- Casing $-15 \mathrm{ft}$ 
- Stickup $-0.24 \mathrm{ft}$ above ground surface

\section{Chicago Sanitary and Ship Canal Data Sensor Configurations and Shot Information (343-cubic-inch water gun)-September 27, 2011}

\section{Files 86.dat through 125.dat}

[PVC, polyvinyl chloride; $\mathrm{ft}$, feet; $\mathrm{lb} / \mathrm{in}^{2}$, pounds per square inch]

\begin{tabular}{ll}
\hline Seismograph channels & \multicolumn{1}{c}{ Sensor location } \\
\hline $1-3$ & Borehole 1, deep 3C geophone \\
$4-6$ & Borehole 1, shallow geophone \\
$7-9$ & Borehole 2, deep 3C geophone \\
$10-12$ & Borehole 2, shallow 3C geophone \\
$13-15$ & Borehole 3, deep 3C geophone \\
$16-18$ & Borehole 3, shallow 3C geophone \\
$19-21$ & 3C geophone in PVC on wall \\
22 & MP-24-3 hydrophone (4 ft below water surface) \\
\hline
\end{tabular}

\begin{tabular}{llc}
\hline \multicolumn{1}{c}{ File } & Water gun pressure $\left(\mathbf{l b} / \mathbf{i n}^{2}\right)$ or noise source & Gun distance from canal wall (ft) \\
\hline 86.dat-87.dat & Background noise & 90 \\
88.dat & 1,000 & \\
89.da-90.dat & Background noise & 90 \\
91.dat & 1,000 & \\
92.dat & Barge & \\
93.dat & Background noise & 90 \\
94.dat-96.dat & 1,500 & \\
97.dat & Background noise & 90 \\
98.dat-99.dat & 1,500 & 30 \\
100.dat-103.dat & 2,000 & 30 \\
104.dat-108.dat & 1,000 & 30 \\
109.dat-113.dat & 1,500 & 30 \\
114.dat & Background noise & \\
115.dat-119.dat & 2,000 & \\
120.dat-123.dat & 500 & Barges \\
124.dat-125.dat & &
\end{tabular}




\section{Files 127.dat through 180.dat (new sensor configuration)}

[ft, feet; PVC, polyvinyl chloride; $\mathrm{lb} / \mathrm{in}^{2}$, pounds per square inch; ch, channel]

\begin{tabular}{ll}
\hline \multicolumn{1}{c}{ Seismograph channels } & \multicolumn{1}{c}{ Sensor location } \\
\hline $1-3$ & Borehole 1, 3C deep 3C geophone \\
$4-6$ & Hydrophone streamer $(3,11$, and $19 \mathrm{ft}$ below water surface) \\
$7-9$ & Borehole 2, deep 3C geophone \\
$10-12$ & Borehole 2, 3C shallow geophone \\
$13-15$ & Borehole 3, deep 3C geophone \\
$16-18$ & Borehole 3, shallow 3C geophone \\
$19-21$ & 3C geophone in PVC on wall (tap test indicates ch 19 perpendicular to canal, \\
22 & ch 20 parallel to canal, ch 21 vertical) \\
\hline
\end{tabular}

\begin{tabular}{llc}
\hline \multicolumn{1}{c}{ File } & Water gun pressure (Ib/in') or noise source & Gun distance from canal wall (ft) \\
\hline 127.dat-136.dat & 2000 & 90 \\
137.dat-145.dat & 2000 & 80 \\
146.dat & Background noise & \\
147.dat & Sailboat & \\
148.dat & 2000 & 80 \\
149.dat & 2000 & 70 \\
150.dat-152.dat & Background noise & \\
153.dat-161.dat & 2000 & \\
162.dat-164.dat & Background noise & \\
165.dat & Barge (with crane) & \\
166.dat & Background noise & 60 \\
167.dat & 2 barges side-to-side & \\
168.dat-177.dat & 2000 \\
178.dat & Background noise & \\
179.dat & Background noise & \\
180.dat & Barge (very slow) & \\
\hline
\end{tabular}




\section{Chicago Sanitary and Ship Canal Data Sensor Configurations and Shot Information (343-cubic-inch water gun)-September 28, 2011}

\section{Files 181.dat through 234.dat}

[ft, feet; $1 \mathrm{~b} / \mathrm{in}^{2}$, pounds per square inch]

\begin{tabular}{ll}
\hline Seismograph channels & \multicolumn{1}{c}{ Sensor location } \\
\hline $1-3$ & Borehole 1, 3C deep 3C geophone \\
$4-6$ & Hydrophone streamer (3, 11, and 19 ft below water surface) \\
$7-9$ & Borehole 2, deep 3C geophone \\
10 & MP-24-3 hydrophone (11.5 ft below water surface) \\
$13-15$ & Borehole 3, deep 3C geophone \\
$16-18$ & Borehole 3, shallow 3C geophone \\
$19-21$ & 3C geophone in PVC on wall \\
22 & MP-24-3 hydrophone (4 ft below water surface) \\
\hline
\end{tabular}

\begin{tabular}{llc}
\hline \multicolumn{1}{c}{ File } & Water gun pressure $\left(\mathbf{l b} / \mathbf{i n}^{2}\right)$ or noise source & Gun distance from canal wall (ft) \\
\hline 181.dat-185.dat & Background noise & 50 \\
186.dat-191.dat & 2,000 & \\
192.dat & Background noise & 50 \\
193.dat-194.dat & 2,000 & \\
195.dat & Background noise & 50 \\
196.dat-197.dat & 2,000 & 40 \\
198.dat & 2,000 & 40 \\
199.dat & Background noise & \\
200.dat-208.dat & 2,000 & 30 \\
209.dat-221.dat & Barge (220.dat barge closest) \\
222.dat & Background noise & \\
223.dat-231.dat & 2,000 & 30 \\
232.dat & Pleasure boat & \\
233.dat & Background noise & \\
234.dat & 2.000 & \\
\hline
\end{tabular}




\section{Files 235.dat through 291.dat}

[PVC, polyvinyl chloride; $\mathrm{ft}$, feet; $\mathrm{psi}$, pounds per square inch; $\mathrm{mV}$, millivolt; $\mathrm{s}$, second]

\begin{tabular}{ll}
\hline \multicolumn{1}{c}{ Seismograph channels } & \multicolumn{1}{c}{ Sensor location } \\
\hline $1-3$ & Borehole 1, deep 3C geophone \\
$4-6$ & Borehole 1, surface 3C geophone \\
$7-9$ & Borehole 2, deep 3C geophone \\
$10-12$ & Borehole 2, surface 3C geophone \\
$13-15$ & Borehole 3, deep 3C geophone \\
$16-18$ & Borehole 3, surface 3C geophone \\
$19-21$ & 3C geophone in PVC on wall \\
$22-24$ & Hydrophone streamer (3, 11, and 19 ft below water surface) \\
\hline
\end{tabular}

\begin{tabular}{llc}
\hline \multicolumn{1}{c}{ File } & \multicolumn{1}{c}{ Water gun pressure (psi) or noise source } & Gun distance from canal wall (ft) \\
\hline 235.dat & Background noise & 30 \\
236.dat-245.dat & 2,000 & 40 \\
246.dat-256.dat & 2,000 & 50 \\
257.dat-268.dat & 2,000 & \\
269.dat & Barge & \\
270.dat & Double barge (side-to-side) \\
271.dat & Double barge with cavitation (peak $89 \mathrm{mV}$ at 230 to 240 s) \\
272.dat-278.dat & Barge backing up \\
279.dat & 2 large pleasure boats \\
\hline
\end{tabular}

Chicago Sanitary and Ship Canal Data Sensor Configurations and Shot Information (80-cubic-inch water gun)_-September 28, 2011

[psi, pounds per square inch; $\mathrm{ft}$, feet]

\begin{tabular}{lcc}
\hline \multicolumn{1}{c}{ File } & $\begin{array}{c}\text { Water gun pressure (psi) or noise source (raindrop impacts } \\
\text { visible on all three surface geophones) }\end{array}$ & Gun distance from canal wall (ft) \\
\hline 280.dat & Background noise & 30 \\
281.dat-285.dat & 2,000 \\
286.dat & Background noise & 30 \\
287.dat-291.dat & 2,000 & 30 \\
\hline
\end{tabular}




\section{Chicago Sanitary and Ship Canal Data Sensor Configurations and Shot Information (80-cubic-inch water gun)—September 29, 2011}

\section{Files 2097.dat through 2135.dat}

[PVC, polyvinyl chloride; ft, feet; psi, pounds per square inch]

\begin{tabular}{ll}
\hline Seismograph channels & \multicolumn{1}{c}{ Sensor location } \\
\hline $1-3$ & Borehole 1, deep 3C geophone \\
$4-6$ & Borehole 1, shallow 3C geophone \\
$7-9$ & Borehole 2, deep 3C geophone \\
$10-12$ & Borehole 2, shallow 3C geophone \\
$13-15$ & Borehole 3, deep 3C geophone \\
$16-18$ & Borehole 3, shallow 3C geophone \\
$19-21$ & 3C geophone in PVC on wall \\
$22-24$ & Hydrophone streamer (3, 11, and 19 ft below water surface) \\
$25-27$ & Surface 3C geophone near Borehole 1 \\
$28-30$ & Surface 3C geophone near Borehole 2 \\
$31-33$ & Surface 3C geophone near Borehole 3 \\
\hline
\end{tabular}

\begin{tabular}{llc}
\hline \multicolumn{1}{c}{ File } & Water gun pressure (psi) or noise source & Gun distance from canal wall (ft) \\
\hline 2097.dat-2100.dat & Background noise & 30 \\
2101.dat-2103.dat & 2,000 & \\
2104.dat & Background noise & 30 \\
2105.dat-2111.dat & 2,000 & \\
2112.dat & Background noise & 30 \\
2113.dat & 2,000 & 40 \\
2114.dat-2123.dat & 2,000 & 50 \\
2124.dat & Barge & \\
2125.dat-2134.dat & 2,000 & \\
2135.dat & Barge & \\
\hline
\end{tabular}




\section{Files 2136.dat through 2138.dat}

[PVC, polyvinyl chloride; ft, feet; NIU, Northern Illinois University; vert., vertical; Hz, hertz]

\begin{tabular}{ll}
\hline \multicolumn{1}{c}{ Seismograph channels } & \multicolumn{1}{c}{ Sensor location } \\
\hline $1-3$ & Borehole 1, deep 3C geophone \\
$4-6$ & Borehole 1, shallow 3C geophone \\
$7-9$ & Borehole 2, deep 3C geophone \\
$10-12$ & Borehole 2, shallow 3C geophone \\
$13-15$ & Borehole 3, deep 3C geophone \\
$16-18$ & Borehole 3, shallow 3C geophone \\
$19-21$ & 3C geophone in PVC on wall \\
$22-24$ & Hydrophone streamer (3, 11, and19 ft below water surface) \\
25 & NIU vert. geophone at Borehole 3 (Mark Prod. L10-B 8.25 Hz) \\
\hline
\end{tabular}

\begin{tabular}{lll}
\hline \multicolumn{1}{c}{ File } & \multicolumn{1}{c}{ Water gun pressure (psi) or noise source } & Gun distance from canal wall (ft) \\
\hline 2136.dat & Background noise & 30 \\
2137.dat -2138.dat & 2,000 & 30 \\
\hline
\end{tabular}

\section{Files 2139.dat through 2142.dat}

[PVC, polyvinyl chloride; ft, feet; NIU, Northern Illinois University; horiz., horizontal; Hz, hertz; psi, pounds per square inch]

\begin{tabular}{ll}
\hline \multicolumn{1}{c}{ Seismograph channels } & \multicolumn{1}{c}{ Sensor location } \\
\hline $1-3$ & Borehole 1, deep 3C geophone \\
$4-6$ & Borehole 1, shallow 3C geophone \\
$7-9$ & Borehole 2, deep 3C geophone \\
$10-12$ & Borehole 2, shallow 3C geophone \\
$13-15$ & Borehole 3, deep 3C geophone \\
$16-18$ & Borehole 3, shallow 3C geophone \\
$19-21$ & 3C geophone in PVC on wall \\
$22-24$ & Hydrophone streamer (3, 11, and 19 ft below water surface) \\
25 & NIU horiz. geophone at Borehole 3 (Mark Prod. L28LBH 4.5 Hz) \\
\hline
\end{tabular}

\begin{tabular}{ccc}
\hline File & Water gun pressure (psi) or noise source & Gun distance from canal wall (ft) \\
\hline 2139.dat -2142 .dat & 2000 & 30 \\
\hline
\end{tabular}




\section{Files 2143.dat through 2144.dat}

[PVC, polyvinyl chloride; ft, feet; NIU, Northern Illinois University; vert., vertical; Hz, hertz; psi, pounds per square inch]

\begin{tabular}{ll}
\hline \multicolumn{1}{c}{ Seismograph channels } & \multicolumn{1}{c}{ Sensor location } \\
\hline $1-3$ & Borehole 1, deep 3C geophone \\
$4-6$ & Borehole 1, shallow 3C geophone \\
$7-9$ & Borehole 2, deep 3C geophone \\
$10-12$ & Borehole 2, shallow 3C geophone \\
$13-15$ & Borehole 3, deep 3C geophone \\
$16-18$ & Borehole 3, shallow 3C geophone \\
$19-21$ & 3C geophone in PVC on wall \\
$22-24$ & Hydrophone streamer (3, 11, and 19 ft below water surface) \\
25 & NIU vert. geophone "A1" at Borehole 3 (Mark Prod. L40A3 50 Hz) \\
\hline
\end{tabular}

\begin{tabular}{lll}
\hline File & Water gun pressure (psi) or noise source & Gun distance from canal wall (ft) \\
\hline 2143.dat -2144.dat & 2000 & 30 \\
\hline
\end{tabular}

\section{Files 2145.dat through 2146.dat}

[PVC, polyvinyl chloride; ft, feet; NIU, Northern Illinois University; vert. comp., vertical component; Hz, hertz; psi, pounds per square inch]

\begin{tabular}{ll}
\hline \multicolumn{1}{c}{ Seismograph channels } & \multicolumn{1}{c}{ Sensor location } \\
\hline $1-3$ & Borehole 1, deep 3C geophone \\
$4-6$ & Borehole 1, shallow 3C geophone \\
$7-9$ & Borehole 2, deep 3C geophone \\
$10-12$ & Borehole 2, shallow 3C geophone \\
$13-15$ & Borehole 3, deep 3C geophone \\
$16-18$ & Borehole 3, shallow 3C geophone \\
$19-21$ & 3C geophone in PVC on wall \\
$22-24$ & Hydrophone streamer (3, 11, and 19 ft below water surface) \\
25 & NIU 3C “A”, vert. comp., at Borehole 3 (Mark Prod. L15B 4.5 Hz) \\
\hline
\end{tabular}




\section{Files 2147.dat through 2148.dat}

[PVC, polyvinyl chloride; ft, feet; NIU, Northern Illinois University; comp., component; Hz, hertz; psi, pounds per square inch]

\begin{tabular}{ll}
\hline \multicolumn{1}{c}{ Seismograph channels } & \multicolumn{1}{c}{ Sensor location } \\
\hline $1-3$ & Borehole 1, deep 3C geophone \\
$4-6$ & Borehole 1, shallow 3C geophone \\
$7-9$ & Borehole 2, deep 3C geophone \\
$10-12$ & Borehole 2, shallow 3C geophone \\
$13-15$ & Borehole 3, deep 3C geophone \\
$16-18$ & Borehole 3, shallow 3C geophone \\
$19-21$ & 3C geophone in PVC on wall \\
$22-24$ & Hydrophone streamer (3, 11, and 19 ft below water surface) \\
25 & NIU 3C “A”, H-1 comp., at Borehole 3 (Mark Prod. L15B 4.5 Hz) \\
\hline
\end{tabular}

\begin{tabular}{lcc}
\hline File & Water gun pressure (psi) or noise source & Gun distance from canal wall (ft) \\
\hline 2147.dat-2148.dat & 2,000 & 30 \\
\hline
\end{tabular}

\section{Files 2149.dat through 2150.dat}

[PVC, polyvinyl chloride; ft, feet; NIU, Northern Illinois University; comp., component; Hz, hertz; psi, pounds per square inch]

\begin{tabular}{ll}
\hline \multicolumn{1}{c}{ Seismograph channels } & \multicolumn{1}{c}{ Sensor location } \\
\hline $1-3$ & Borehole 1, deep 3C geophone \\
$4-6$ & Borehole 1, shallow 3C geophone \\
$7-9$ & Borehole 2, deep 3C geophone \\
$10-12$ & Borehole 2, shallow 3C geophone \\
$13-15$ & Borehole 3, deep 3C geophone \\
$16-18$ & Borehole 3, shallow 3C geophone \\
$19-21$ & 3C geophone in PVC on wall \\
$22-24$ & Hydrophone streamer (3, 11, and 19 ft below water surface) \\
25 & NIU 3C, H-2 comp., at Borehole 3 (Mark Prod. L15B 4.5 Hz) \\
\hline
\end{tabular}

\begin{tabular}{ccc}
\hline File & Shot size (psi) or noise source & Gun distance from canal wall (ft) \\
\hline 2 2149.dat-2150.dat & 2,000 & 30 \\
\hline
\end{tabular}




\section{Files 2151.dat through 2152.dat}

[PVC, polyvinyl chloride; ft, feet; NIU, Northern Illinois University; vert. comp., vertical component; Hz, hertz; psi, pounds per square inch]

\begin{tabular}{ll}
\hline \multicolumn{1}{c}{ Seismograph Channels } & \multicolumn{1}{c}{ Sensor Location } \\
\hline $1-3$ & Borehole 1, deep 3C geophone \\
$4-6$ & Borehole 1, shallow 3C geophone \\
$7-9$ & Borehole 2, deep 3C geophone \\
$10-12$ & Borehole 2, shallow 3C geophone \\
$13-15$ & Borehole 3, deep 3C geophone \\
$16-18$ & Borehole 3, shallow 3C geophone \\
$19-21$ & 3C geophone in PVC on wall \\
$22-24$ & Hydrophone streamer (3, 11, and 19 ft below water surface) \\
25 & NIU, vert. comp. “\#10”, next to Borehole 2 \\
\hline
\end{tabular}

\begin{tabular}{llc}
\hline File & Shot size (psi) or noise source & Gun distance from canal wall (ft) \\
\hline 2151.dat -2152.dat & 2,000 & 30 \\
\hline
\end{tabular}

\section{Files 2153.dat through 2155.dat}

[PVC, polyvinyl chloride; ft, feet; NIU, Northern Illinois University; vert, comp., vertical component; Hz, hertz; psi, pounds per square inch]

\begin{tabular}{ll}
\hline \multicolumn{1}{c}{ Seismograph channels } & \multicolumn{1}{c}{ Sensor location } \\
\hline $1-3$ & Borehole 1, deep 3C geophone \\
$4-6$ & Borehole 1, shallow 3C geophone \\
$7-9$ & Borehole 2, deep 3C geophone \\
$10-12$ & Borehole 2, shallow 3C geophone \\
$13-15$ & Borehole 3, deep 3C geophone \\
$16-18$ & Borehole 3, shallow 3C geophone \\
$19-21$ & 3C geophone in PVC on wall \\
$22-24$ & Hydrophone streamer (3, 11, and 19 ft below water surface) \\
25 & NIU, vert. comp. “\#9”, next to Borehole 2 \\
\hline
\end{tabular}

\begin{tabular}{rcc}
\hline File & Water gun pressure (psi) or noise source & Gun distance from canal wall (ft) \\
\hline 2153. dat & 2,000 & 30 \\
2154. dat & 2,000 & 30 \\
2155. dat & Background noise & \\
\hline
\end{tabular}




\section{Coal Facility-October 20, 2011}

All data were collected with a Geometrics Geode seismograph with SGOS running on either NIU's Xplore tablet computer or a USGS Dell laptop computer. Geophones were deployed along a north-south line with 30-ft spacing. The line of geophones was approximately $50 \mathrm{ft}$ west of the CSSC and $200 \mathrm{ft}$ north of barge coal-loading operations. Railroad tracks bordered the opposite (east) side of the canal. Channel order on the 3C geophones was always vertical, H-1(EW) and H-2 (NS). The pointed side of each geophone was oriented north.

\section{Files 1.dat through 7.dat}

$[\mathrm{Hz}$, hertz $]$

\begin{tabular}{ll}
\hline \multicolumn{1}{l}{ Seismograph channels } & \multicolumn{1}{c}{ Sensor location } \\
\hline $1-3$ & \multicolumn{1}{c}{ Southernmost 3C geophone $(10 \mathrm{~Hz})$} \\
$4-6$ & Next 3C geophone to the north $(10 \mathrm{~Hz})$ \\
$7-9$ & Next 3C geophone to the north $(10 \mathrm{~Hz})$ \\
$10-12$ & Next 3C geophone to the north $(10 \mathrm{~Hz})$ \\
$13-15$ & \multicolumn{1}{c}{ Everthernmost 3C geophone $(10 \mathrm{~Hz})$} \\
\hline \multicolumn{1}{c}{ File } & \multicolumn{1}{c}{ Background noise } \\
\hline 1.dat & Coal loading \\
2.dat & Coal loading \\
3.dat & Train \\
4.dat & Train and coal loading \\
5.dat & 2 trains \\
6.dat & Coal loading \\
7.dat &
\end{tabular}

Files 8.dat through 13.dat (All $3 \mathrm{C}$ geophones refer to the 10-Hz geophones, unless otherwise specified)

[Hz, hertz; NIU, Northern Illinois University; vert. comp., vertical component]

\begin{tabular}{ll}
\hline \multicolumn{1}{c}{ Seismograph channels } & \multicolumn{1}{c}{ Sensor location } \\
\hline $1-3$ & Southernmost 3C geophone (10 Hz) \\
6 & NIU horizontal geophone, oriented north-south (no number) \\
7 & NIU horizontal geophone, oriented east-west (\#4) \\
8 & NIU high-frequency vertical geophone (\#17) \\
9 & Low-frequency vertical geophone (\#11) \\
$10-12$ & NIU 3C, vert. comp. (\#8) (Mark Prod. L15B 4.5 Hz): ch $10 \mathrm{H}-2$ (west), ch $11 \mathrm{~V}$, ch $12 \mathrm{H}-1$ (north) \\
$13-15$ & Northernmost 3C geophone (10 Hz) \\
\hline
\end{tabular}




\section{Railroad, Barge, and Vehicle Traffic}

\section{Railroad Traffic at the Electric Barrier (October 20 and November 1, 2011)}

On October 20, 2011, and November 1, 2011, background noise was collected near the electric fish barrier at Lemont, Illinois. A 25-ft-long square array was constructed approximately $200 \mathrm{ft}$ north of the northern end of the electric fish barrier and approximately $60 \mathrm{ft}$ east of the CSSC and $140 \mathrm{ft}$ west of the north-south-trending railroad tracks. The array consisted of four 3C surface geophones at each corner of the square and one $3 \mathrm{C}$ geophone located in the center of the square. The center of the square array was approximately $50 \mathrm{ft}$ east from the east edge of the CSSC and approximately $135 \mathrm{ft}$ west of the west edge of the pair of north-south railroad tracks. Two datasets of freight trains passing were collected on October 20, and seven datasets of freight trains passing were collected on November 1, 2011. The 3C geophones were all oriented north. Data were collected at 16-ms intervals for $260 \mathrm{~s}$.

\section{Files 14.dat through 19.dat (October 20, 2011)}

\begin{tabular}{ll}
\hline \multicolumn{1}{c}{ Seismograph channels } & \multicolumn{1}{c}{ Sensor location } \\
\hline $1-3$ & Surface 3C geophone, southwest corner \\
$4-6$ & Surface geophone, southeast corner \\
$7-9$ & Surface geophone, northeast corner \\
$10-12$ & Surface geophone, northwest corner \\
$13-15$ & Surface 3C geophone, center of square array \\
\hline
\end{tabular}

\begin{tabular}{cl}
\hline \multicolumn{1}{c}{ File } & \multicolumn{1}{c}{ Event } \\
\hline 14.dat & Wind and background noise \\
15.dat & Freight train (from north) \\
16.dat & Barge tug \\
17.dat & Barge and truck on road east of array \\
18.dat & Background noise \\
19.dat & Freight train (from south, fast) \\
\hline
\end{tabular}


Files 3.dat through 9.dat-November 1, 2011

\begin{tabular}{ll}
\hline Seismograph channels & \multicolumn{1}{c}{ Sensor location } \\
\hline $1-3$ & Surface 3C geophone, southwest corner \\
$4-6$ & Surface 3C geophone, southeast corner \\
$7-9$ & Surface 3C geophone, northeast corner \\
$10-12$ & Surface 3C geophone, northwest corner \\
$13-15$ & Surface 3C geophone, center of square array \\
\hline
\end{tabular}

\begin{tabular}{ll}
\hline \multicolumn{1}{c}{ File } & \multicolumn{1}{c}{ Number of Train Engines } \\
\hline 3.dat & 3 \\
4.dat & 4 \\
5.dat & 3 \\
6.dat & 3 \\
7.dat & Unknown - Collected data after train engines had passed \\
8.dat & 2 \\
9.dat & 2 \\
\hline
\end{tabular}



